\title{
Visualized information value model result of landslide vulnerability in Purworejo
}

Sudaryatno Sudaryatno, Prima Widayani, Totok Wahyu Wibowo, Bayu Aji Sidiq Pramono, Zulfa Nur'aini 'Afifah, et al.

Sudaryatno Sudaryatno, Prima Widayani, Totok Wahyu Wibowo, Bayu Aji Sidiq Pramono, Zulfa Nur'aini 'Afifah, Awit Dini Meikasari, Muhammad Rizki Firdaus, "Visualized information value model result of landslide vulnerability in Purworejo," Proc. SPIE 11311, Sixth Geoinformation Science Symposium, 113110I (21 November 2019); doi: 10.1117/12.2546121

SPIE Event: Sixth Geoinformation Science Symposium, 2019, Yogyakarta, Indonesia 


\title{
Visualized Information Value Model Result of Landslide Vulnerability in Purworejo
}

\author{
Sudaryatno ${ }^{1}$, Prima Widayani ${ }^{1}$, Totok Wahyu Wibowo ${ }^{1}$, Bayu Aji Sidiq Pramono ${ }^{1}$, Zulfa \\ Nur'aini 'Afifah ${ }^{1}$, Awit Dini Meikasari ${ }^{1}$, Pasya Karunia Kusumawardhani ${ }^{1}$, Muhammad Rizki \\ Firdaus ${ }^{1}$ \\ ${ }^{1}$ Dept. of Geographic Information Science, Universitas Gadjah Mada, Bulaksumur, Yogyakarta \\ 55281, sudaryatno@ugm.ac.id \\ Corresponding author's email: \\ sudaryatno@ugm.ac.id
}

\begin{abstract}
Indonesia is one of the disaster-prone countries. Based on the Indonesian Disaster Information Data (DIBI) and the National Disaster Management Agency (BNPB) in the last five years from 2014 to April 2019 there have been 65 landslides in Purworejo. Landslide is one of the most common disaster that occur in Indonesia. Landslide is caused by meteorological and geomorphological factors. Purworejo is one of the potential areas that could be experiencing landslides, because the geomorphological conditions which are included in Menoreh Hills are geographically sloping to very steep. Landslide susceptibility modeling in Purworejo Regency was carried out using three different methods, namely Information Value Model (IVM), Information Value Model-Analytical Hierarchy Process (IVM-AHP) and Information Value Model-Gray Clustering (IVM-GC). The difference between this research and the landslide modeling research that has been done previously is in the geovisualization section. Research that has been done to model landslide vulnerability is visualized in the form of a two-dimensional map. This research develops visualization techniques with the aim of making reading easier, increasing traction, and adding height information and impressions to map readers. The visualization used is 3-dimensional mapping. This mapping is intended to make it easier to compare the map results of modeling that have been done before. The expected results of this study are accurate and reliable 3-dimensional visualization to study the advantages and disadvantages of each of the modeling methods used.
\end{abstract}

Keywords: Landslide, vulnerability factors, visualization, 3-dimensional mapping, Information Value Model

\section{INTRODUCTION}

According to Indonesia Prone Disaster Indeks 2016 (IRBI) from National Disaster Management Agency (BNPB) Indonesia have some numerous landslides and it has been 2.425 landslide occurrence from 2011 until 2015 with Central Java Province has the most frequent landslides event among another regency (National Disaster Management Agency, 2016) ${ }^{[1]}$. Purworejo Regency as the part of Central Java Province in the last five years from 2014 to April 2019 have some 65 landslide with the most enormous years of the event is 2019 or have 15 landslide occurrence (Indonesian Disaster Information Data, 2019) ${ }^{[2]}$. Based on previous research about landslides in Purworejo Regency, there are several factors that cause Purworejo is the potential area of landslide location, including condition of slope in Menoreh Hills and soil threshold as main factors and rainfall intensity that can trigger landslides in each type of lithology (Ferardi, Wilopo and Fathani, 2018 ${ }^{[3]}$. Another research with the same concerns put human activities than derived by physical conditions were slope cutting for: road construction, houses, agricultural purposes, and sand and stone mining in the river canal as one of the factor that induced landslide in the study area according to the result spatial data distribution of most landslide (>90\%) were parallel with road networks (Sartohadi, 2008) ${ }^{[4]}$.

This research is aim to make it easier to compare the map results of modeling that have been done before in mapping and modeling aspect, understanding the factors for influence landslides in different method of mapping and modeling, and the expected results of this study are accurate and reliable 3-dimensional visualization to study the advantages and disadvantages of each of the modeling methods used for another application. The difference between this research and the landslide modeling research that has been done previously is in the geovisualization section. Research that has been done to model landslide vulnerability is visualized in the form of a two-dimensional map. This research develops visualization techniques with the aim of making reading easier, increasing traction, and adding height information and impressions to map readers.

Sixth Geoinformation Science Symposium, edited by Sandy Budi Wibowo, Andi B. Rimba

Stuart Phinn, Ammar A. Aziz, Proc. of SPIE, Vol. 11311, 113110I · (C) 2019 SPIE

CCC code: $0277-786 \mathrm{X} / 19 / \$ 21 \cdot$ doi: $10.1117 / 12.2546121$

Proc. of SPIE Vol. 11311 113110I-1 


\section{METHODOLOGY}

\subsection{Research Area}

The study area is Purworejo as shown at figure 1 below. Purworejo as Regency in the part of Central Java Province was due to the fact that in the last five years from 2014 to April 2019 have some 65 landslide with the most enormous years of the event is 2019 or have 15 landslide occurrence (Indonesian Disaster Information Data, $2019)^{[2]}$. Administratively the Purworejo district consists of 16 sub-districts, which are divided into 494 villages. Geographically, Purworejo Regency is located in the south-central part of Java Island, more precisely located at $8^{\circ} 30^{\prime}-7^{\circ} 20^{\prime}$ South Latitude, and $109^{\circ} 47^{\prime} 28^{\prime \prime}-111^{\circ} 8^{\prime} 20^{\prime \prime}$ East Longitude

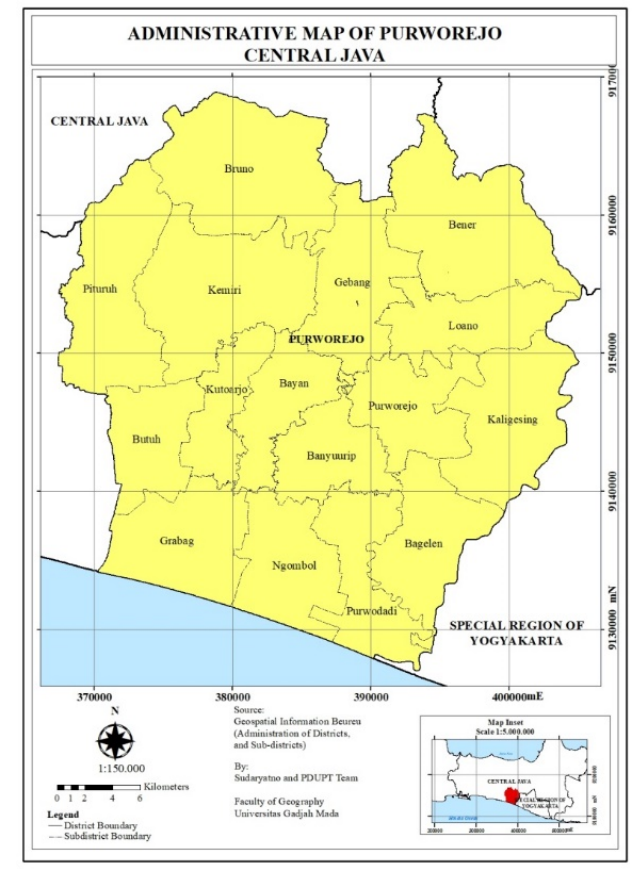

Figure 1. Research Area Map

\subsection{Research Steps}

\subsubsection{Data Synchronization}

Penyelarasan data merupakan proses yang hampir pasti dilakukan dalam membuat pemodelan spasial. Data tidak dapat diolah lebih lanjut jika data - data tersebut belum diselaraskan, misalnya dalam hal geometri, radiometrik (data raster), dan sebagainya. Hasil dari proses penyelarasan data adalah basis data yang sudah rapi dan selaras, serta siap untuk dioleh. Penyelarasan data sangat penting dilakukan untuk menghindari redundasi data.

Data synchronization is a process that is almost certainly used in making spatial modeling. Data cannot be further processed if the data has not been harmonized, for example in terms of geometry, radiometrics (raster data), and so on. The result of the data synchronization process is a database that is neat and aligned, and ready to be obtained. Data synchronization is very important to avoid data redundation.

Munculnya data yang redundan merupakan salah satu konsekuensi dalam penggunaan banyak parameter dalam suatu pemodelan. Pada penelitian ini, data yang diperoleh memiliki redundansi yang cukup besar. Terutama pada data - data mentah yang merupakan parameter dalam membuat pemodelan IVM, seperti data curah hujan, elevasi, arah hadap lereng, dan sebagainya. Tahap pertama dalam melakukan penyelerasan data adalah menentukan data yang dianggap paling ideal. Pada penelitian ini, data elevasi dianggap paling ideal. Sehingga data tersebut dijadikan referensi untuk menyelaraskan data - data lain. 
The emergence of redundant data is one consequence of using many parameters in a modeling. In this study, the data obtained has considerable redundancy. Especially on raw data which is a parameter in making IVM modeling, such as rainfall data, elevation, slope facing direction, and so on. The first stage in synchronizing data is to determine the data that are considered the most ideal. In this study, elevation data is considered the most ideal. So that the data is used as a reference to harmonize other data.

\subsubsection{Converting IVM Model Landslides from vector types to raster types}

Landslide IVM modeling is formed from a database composed of data synchronization processes. IVM modeling has been done by three different methods, namely weightless IVM modeling, IVM-AHP (Analytical Hierarchy Process) modeling, and IVM-GC (Gray Clustering) modeling. Three modeling methods produce modeling products with vector types. 3D visualization can only be done in vector form, because the height data that is owned is raster data. In addition, the type of shepherd raster data is more easily processed to be $3 \mathrm{D}$ than vector data.

Conversion processed by utilizing the Geographic Information System (GIS) to produce raster data modeling of landslide susceptibility by three different methods (IVM, IVM-AHP, and IVM-GC). There are no changes in data attributes or spatial data components. It is just that the data attributes become more concise. Each pixel of the raster data shows a different level of vulnerability. Raster data for each of these modeling will then be used as input data to design a 3D model of landslide susceptibility.

\subsubsection{Designing 3D Modelling of Landslide in Purworejo}

$3 \mathrm{D}$ modeling is one of the geovisualisations that utilize altitude data to produce a more pronounced height impression. Height data can be obtained from various sources, such as contour data, DEM (Digital Elevation Model), and so on. Things to consider in selecting height data are spatial resolution. The spatial resolution used must be in harmony with the spatial resolution of other data. It is not recommended if altitude data has a lower resolution compared to other data. However, if the elevation data has a slightly higher resolution it can still be tolerated with certain conditions.

In this study, the height data used is DEM Alos Palsar data with a spatial resolution of 10 meters. DEM Alos Palsar is altitude data obtained from image recording with the microwave (radar) channel of the ALOS satellite. Alos Palsar DEM was chosen to be used as elevation data because the Alos Palsar DEM has spatial resolution that is in harmony with the data making up of the IVM model.

The process of making three-dimensional geovisualization can be done in vaious ways. In this study, geovisualization was designed by utilizing the QGIS with the QGIS2threejs plugin. Qgis2threejs plugin is a QGIS plugin, which visualizes DEM data and vector data in 3D on a web view. 


\section{DATA}

The data used in this study are nine landslide parameter data, namely land use, rainfall, elevation, direction of slope, slope, distance from fault, distance from road network, distance from hydrographic network and vegetation index (NDVI). Land use was obtained from Landsat 8 imagery using multispectral classification methods. Rainfall is obtained from annual cumulative rainfall data because the data can represent rainfall in a year. Furthermore, the elevation is constructed from a contour map at $12.5 \mathrm{~m}$ intervals using the topo to raster algorithm which then results are reduced to the direction facing the slope and the slope. The distance from the fault is obtained from the geological map that is the fault line in the form of a vector which is then buffered. Likewise with the distance from the network which is the result of buffer from the road network vector data, and the distance from the hydrological network which is the result of buffer from the river vector data. In this study, the vegetation index was obtained from known vegetation densities based on field checks and calculated using the NDVI index transformation

\section{RESULTS}

\subsection{Information Value Model (IVM) untuk Memodelkan Kerawanan Longsor}

Information Value Model (IVM) is a modeling method that develops from information theory to conduct statistical analysis. Based on this model, the parameter information that causes landslides is used as input data to model the landslide vulnerability (nine landslide parameter data). The formula below shows the information value I (xi, $\mathrm{H}$ ) of each of the landslide parameters xi $(I=1,2,3, \ldots \ldots, n)$.

$$
I(x i, H)=\ln \frac{N i / N}{S i / S}
$$

$H$ in the formula above shows the possibility of landslides, $S$ shows the total mapping unit, $N$ is the area of the landslide in the study area, and $\mathrm{Si}$ is the number of mapping units in the presence of a predisposing factor xi. The total information I of each mapping unit can be calculated by adding up the information values of all the predisposing factors. The resulting value can be a positive or negative value, with the following class. If $\mathrm{I}<0$, the probability of landslides is lower than average; If $\mathrm{I}=0$, the probability of a landslide is equal to the average; And if $\mathrm{I}>0$, the probability of landslides is higher than average (Ba et al., 2017). In other words, the higher the value of information, the higher the probability of a landslide occurrence.

The total information I of each mapping unit can be calculated by adding up the information values of all the predisposing factors. The resulting value can be a positive or negative value, with the following class. If $\mathrm{I}<0$, the probability of landslides is lower than average; If $\mathrm{I}=0$, the probability of a landslide is equal to the average; And if I $>0$, the probability of landslides is higher than average (Ba et al., 2017). In other words, the higher the value of information, the higher the probability of a landslide occurrence. 


\begin{tabular}{|c|c|c|c|c|c|c|c|c|c|}
\hline PARAMETERS & Slope & Aspect & Elevation & $\begin{array}{c}\text { Distance } \\
\text { from } \\
\text { fault }\end{array}$ & $\begin{array}{c}\text { Distance } \\
\text { from } \\
\text { hydrology } \\
\text { feature }\end{array}$ & $\begin{array}{c}\text { Distance } \\
\text { from } \\
\text { road }\end{array}$ & Rainfall & Index & Weight \\
\hline Slope & 1 & 9 & 6 & 4 & 7 & 7 & 2 & 7 & 0,351 \\
\hline Aspect & $1 / 3$ & 1 & $1 / 6$ & $1 / 6$ & $1 / 3$ & $1 / 3$ & $1 / 9$ & $1 / 3$ & 0,019 \\
\hline Elevation & $1 / 6$ & 6 & 1 & 1 & 9 & 2 & $1 / 5$ & 3 & 0,082 \\
\hline $\begin{array}{c}\text { Distance from } \\
\text { fault }\end{array}$ & $1 / 4$ & 7 & 3 & 1 & 6 & 5 & $1 / 3$ & 3 & 0,155 \\
\hline $\begin{array}{c}\text { Distance from } \\
\text { hydrology } \\
\text { feature }\end{array}$ & $1 / 7$ & 3 & $1 / 3$ & $1 / 3$ & 1 & 3 & $1 / 7$ & 4 & 0,059 \\
\hline $\begin{array}{c}\text { Distance from } \\
\text { road }\end{array}$ & $1 / 7$ & 3 & $1 / 2$ & $1 / 2$ & $1 / 3$ & 1 & $1 / 5$ & 2 & 0,041 \\
\hline Rainfall & $1 / 2$ & 9 & 5 & 5 & 7 & 5 & 1 & 5 & 0,258 \\
\hline NDVI & $1 / 7$ & 3 & $1 / 3$ & $1 / 3$ & $1 / 4$ & $1 / 2$ & $1 / 5$ & 1 & 0,035 \\
\hline
\end{tabular}

The Information Value Model-Gray Clustering (IVM-GC) method is a method with a more objective weighting because the weighting determination is calculated mathematically. Slope of $20-35^{\circ}$, direction facing east and northeast slopes, elevation of 100-200 meters, distance of fault from 1200-1800 meters, distance from river 1000-2000 meters, distance from road $600-800$, rainfall $>120 \mathrm{~mm} /$ months and NDVI $<0.55$ belong to classes that have very high landslide vulnerabilities (Ba et al., 2017).

\subsection{Geovisualisasi Tiga Dimensi untuk Kerawanan Longsor}

The 3-dimensional visualization for the results of IVM modeling for landslides was aimed to making observation of landslide vulnerability in Purworejo District easier and more effective. 3-dimensional modeling was carried out for all three modeling results, IVM, IVM-GC and IVM-AHP. Each of the 3-dimensional visualization results is displayed using the ALOS PALSAR data elevation model (DEM) which covers the study area of Purworejo District. The following in table 2 is a comparison of the results of 3-dimensional visualization for the three results of IVM modeling: 
Table 2. Comparison table of 3D Maps

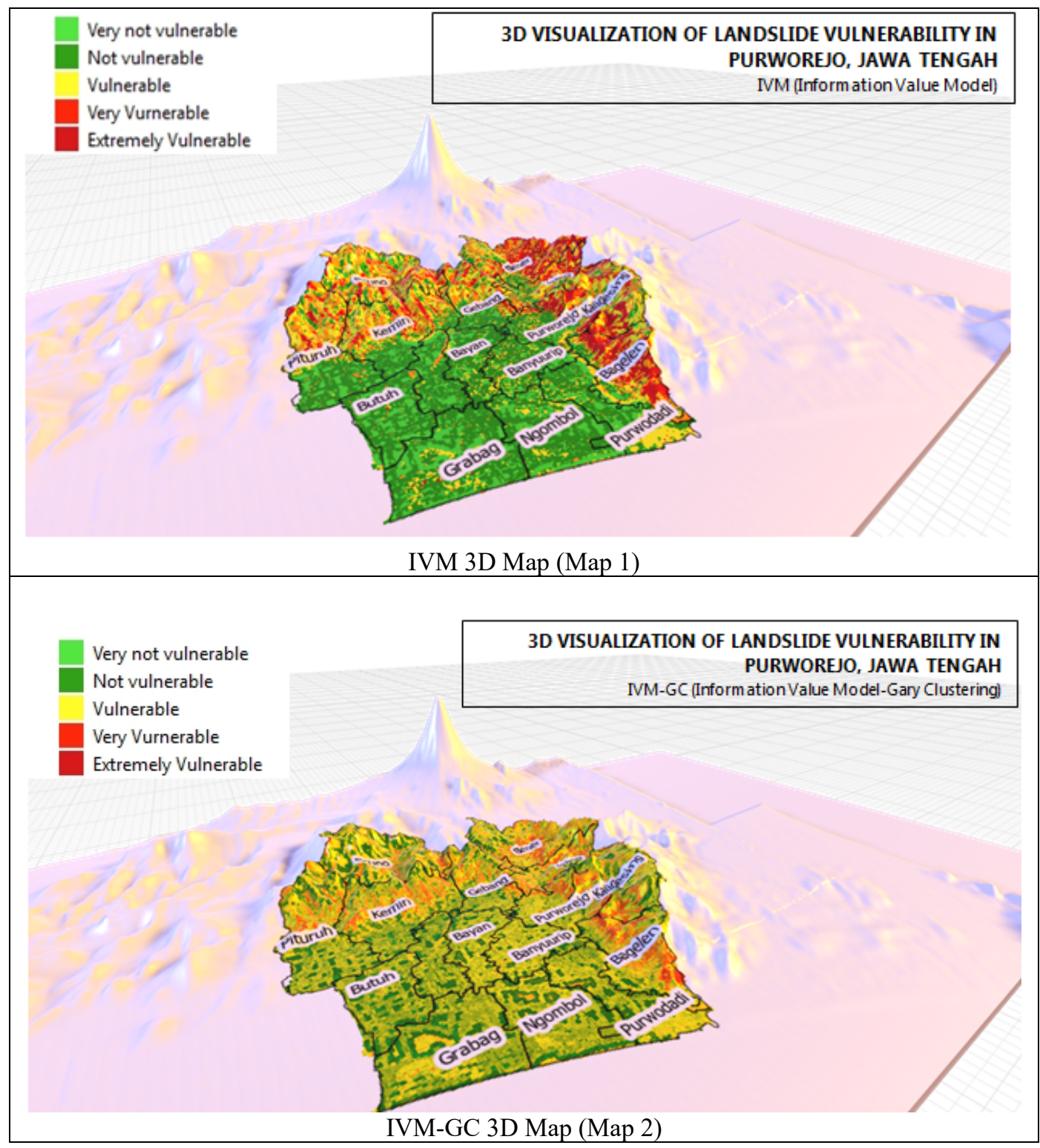

Proc. of SPIE Vol. 11311 113110I-6 


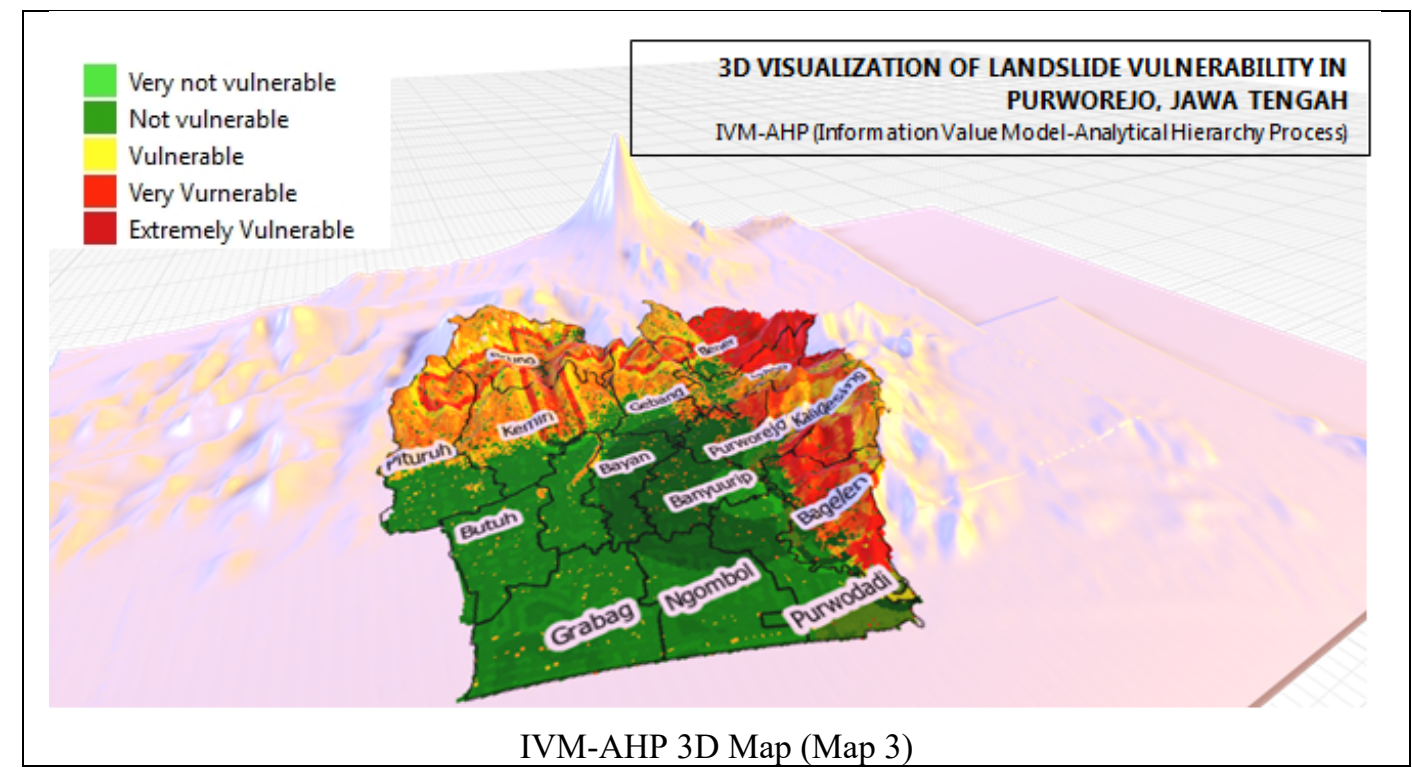

Based on the above 3-dimensional visualization, it can be seen that IVM modeling is easier to interpret in accordance with the actual field elevation condition because the addition of $\mathrm{z}$ factor is in the study area elevation. The 3dimensional visualization for IVM modeling shows the spatial distribution of linearity between landslide vulnerabily and study area elevation. The 3-dimensional observation for IVM modeling showed the highest level of vulnerability of landslides and evenly distributed in Bener Subdistrict, Loano Subdistrict, Kaligesing Subdistrict and Bagelen Subdistrict. 3-dimensional visualization for IVM-GC modeling shows results similar to IVM modeling discussed earlier. In the 3-dimensional IVM-GC visualization modeling, it can be found that "Vulnarable" zone is more evenly distributed throughout the study area. While the 3-dimensional visualization for IVM-AHP modeling looks different than the two previous models. Although IVM-AHP visualization is sufficient, it shows that vulnerability is also linear with study area elevation, but the visualization seems less realistic compared to IVM and IVM-GC.

The IVM-AHP method is the method that has the most uneven results compared to the two methods used in this study. That is because this method uses subjective weighting. Thus, if different researchers apply it will produce different levels of vulnerability to landslides. Objective weighting is needed so that results are more permanent and can be accounted for mathematically.

The level of landslide susceptibility is very high spread in the northeast to the east. In the northwest to the north is dominated by a high level of vulnerability to landslides to very high. Whereas in the south, the most dominant level of landslide susceptibility is low to moderate. The level of landslide susceptibility is obtained from the classification of total IVM values, where total IVM is the accumulated value of IVM for each parameter that has previously been multiplied by the weighting factor per parameter that has been mathematically calculated. The level of landslide susceptibility is more evenly distributed in the results using the IVM-GC method compared to IVM-AHP or IVM. The distribution pattern of landslide susceptibility level is in line with the pattern of slope, rainfall, distance from the road, distance from fault and elevation.

Results of IVM, IVM-AHP and IVM-GC, in general have the same distribution. The northeast to the east have the highest vulnerability, the northwest to the north have a moderate level of vulnerability and the south has a low level of landslide vulnerability. The distribution is in line with the distribution of the distance from the fault, the distance from the road and rainfall because the value of the IVM parameter is higher than other IVM values. So that these parameters have the greatest influence on the level of landslide susceptibility.

Overall, each classification of vulnerability is linear with study area elevation. If the elevation is high, the vulnerability of landslides is also high. It can be observed that the similarities in each of the 3-dimensional visualization results in the eastern zone of the study area include Bener Subdistrict, Loano Subdistrict, Kaligesing Subdistrict and Bagelen 
Subdistrict. The 3-dimensional visualization results that can show realistic results are in the 3-dimensional visualization of IVM-GC modeling, considering that the IVM-GC modeling places the elevation factor as the most influential factor on landslide vulnerability.

\section{CONCLUSIONS}

Based on the research that has been done, the conclusion is obtained to answer the research objectives as follows:

1. Purworejo is prone to landslides in areas with hilly to mountainous topography. This applies to all types of landslide vulnerability modeling.

2. Results of IVM, IVM-AHP and IVM-GC, in general have the same distribution. The northeast to the east have the highest vulnerability, the northwest to the north have a moderate level of vulnerability and the south has a low level of landslide vulnerability.

3. Visually, it appears that the results of IVM modeling that are best suited to be visualized in the form of threedimensional maps are landslide modeling using the IVM-GC method. The 3-dimensional visualization for IVM, IVMGC and IVM-AHP landslide vulnerability modeling can show linearity between landslide vulnerability and study area elevation. The 3-dimensional visualization can help observe landslide vulnerability is more realistic and effective, especially in IVM-GC modeling. Results of IVM, IVM-AHP and IVM-GC, in general have the same distribution. The northeast to the east has the highest vulnerability, the northwest to the north has a moderate level of vulnerability and the south has a low level of landslide vulnerability.

\section{REFERENCES}

[1] National Disaster Management Agency, "Indonesia Prone Disaster Indeks (RBI) 2016”, Central Jakarta, National Disaster Management Agency, Directorate of Disaster Risk Reduction. 86p (2016)

[2] National Disaster Management Agency, "Indonesian Disaster Information Data (DIBI) Landslide Purworejo Regency 2019". Central Jakarta, National Disaster Management Agency, Directorate of Disaster Risk Reduction, https://bnpb.cloud/dibi/laporan5 (2019)

[3] Ferardi, F. D., Wilopo, W., \& Fathani, T. F. "Rainfall Thresholds for Landslide Prediction in Loano Subdistrict, Purworejo District Central Java Province”. Journal of Applied Geology, 3(1), 23. 10.22146/jag.40001. (2018).

[4] Sartohadi, Junun. "The Landslide Distribution in Loano Sub-District the Landslide Distribution in Loano SubDistrict, Purworejo District, Central Java Province, Indonesia”. Forum Geografi. 22. 10.23917/forgeo.v22i2.4987. (2008).

[5] Ba, Q., Chen, Y., Deng, S., Wu, Q., Yang, J., \& Zhang, J. “An Improved Information Value Model Based on Gray Clustering for Landslide Susceptibility Mapping.” ISPRS International Journal of Geo-Information, 6(1), 18.

10.3390/ijgi6010018 (2017). 